\title{
Long-term follow-up of 114 patients with congenital hyperinsulinism
}

\author{
Thomas Meissner, Udo Wendel, Peter Burgard ${ }^{1}$, Silvia Schaetzle ${ }^{1}$ and Ertan Mayatepek \\ Clinic of General Pediatrics, University Children's Hospital, Düsseldorf, Germany and ${ }^{1}$ Division of Metabolic and Endocrine Diseases, \\ University Children's Hospital, Heidelberg, Germany
}

(Correspondence should be addressed to E Mayatepek, Clinic of General Pediatrics, University Children's Hospital, Moorenstr. 5, D-40225 Düsseldorf, Germany; Email: mayatepek@uni-duesseldorf.de)

\begin{abstract}
Background: The term congenital hyperinsulinism (CHI) comprises a group of different genetic disorders with the common finding of recurrent episodes of hyperinsulinemic hypoglycemia.

Objective: To evaluate the clinical presentation, diagnostic criteria, treatment and long-term follow-up in a large cohort of $\mathrm{CHI}$ patients.

Patients: The data from 114 patients from different hospitals were obtained by a detailed questionnaire. Patients presented neonatally $(65 \%)$, during infancy $(28 \%)$ or during childhood $(7 \%)$.

Results: In 20 of $74(27 \%)$ patients with neonatal onset birth weight was greatly increased (group with standard deviation scores (SDS) >2.0) with a mean SDS of 3.2. Twenty-nine percent of neonatal-onset vs $69 \%$ of infancy/childhood-onset patients responded to diazoxide and diet or to a carbohydrate-enriched diet alone. Therefore, we observed a high rate of pancreatic surgery performed in the neonatal-onset group (70\%) compared with the infancy/childhood-onset group (28\%). Partial $(3 \%)$, subtotal $(37 \%)$ or near total $(15 \%)$ pancreatectomy was performed. After pancreatic surgery there appeared a high risk of persistent hypoglycemia (40\%). Immediately post-surgery or with a latency of several years insulin-dependent diabetes mellitus was observed in operated patients $(27 \%)$. General outcome was poor with a high degree of psychomotor or mental retardation (44\%) or epilepsy (25\%). An unfavorable outcome correlated with infancy-onset manifestation $\left(\chi^{2}=6.1\right.$, $P=0.01)$.

Conclusions: The high degree of developmental delay, in particular in infancy-onset patients emphasizes the need for a change in treatment strategies to improve the unfavorable outcome. Evaluation of treatment alternatives should take the high risk of developing diabetes mellitus into account.
\end{abstract}

European Journal of Endocrinology 149 43-51

\section{Introduction}

Congenital hyperinsulinism (CHI) is the most common cause for recurrent episodes of hypoglycemia in early childhood (1). Different underlying genetic defects have been described during the previous years $(2,3)$. Germline mutations are known for the sulfonylurea receptor gene and the Kir6.2 gene affecting the function of the $\beta$-cell $\mathrm{K}_{\mathrm{ATP}}$-channel, as well as for the genes of glutamate dehydrogenase and glucokinase resulting in overactivity of these enzymes. Whereas germline mutations affecting all pancreatic $\beta$-cells result in so called 'diffuse' disease, somatic recessive disorder is caused by loss of maternal alleles of the imprinted region $11 \mathrm{p} 15$ in pancreatic lesions with 'focal' adenomatous hyperplasia, and usually a germline mutation on the paternal allele. However, management of patients with $\mathrm{CHI}$ still mainly depends on clinical parameters $(4,5)$. Results from mutational analyses are usually not available when important clinical decisions regarding conservative or surgical treatment have to be made, especially in patients nonresponding to diazoxide. However, neither subtotal ( $80-94 \%$ resection) nor near total ( $>95 \%$ resection) pancreatectomy are always sufficient to ensure postoperative euglycemia $(6-10)$. Today, it is known that this might be due to the presence of overlooked focal lesions, especially localized in the head of the pancreas. Besides this, undirected extensive pancreatic resection is associated with a high risk of developing diabetes mellitus $(11,12)$. An alternative drug for long-term treatment is long-acting somatostatin (octreotide) in addition to a carbohydrate-enriched diet and frequent feedings (13). In this heterogeneous group the choice between surgical and non-surgical treatment for an individual patient is still crucial. 
We conducted a retrospective study that was larger in the number of cases and wider in age groups than most previous studies performed so far. We evaluated the course of 114 patients with $\mathrm{CHI}$ with respect to clinical manifestation, diagnostic criteria, management and outcome. These data are discussed with special respect to their impact on recently proposed management strategies $(9,14,15)$, including pancreatic venous sampling and intra-operative histology of the pancreas in order to identify focal pancreatic lesions.

\section{Materials and methods}

This study was based on the German database on congenital hyperinsulinism located at the Clinic of General Pediatrics, University Children's Hospital in Düsseldorf, Germany. At present, data from 114 patients (54 females and 60 males) with persistent hyperinsulinism are registered. The patients' origins are from Germany (91), Turkey (14), Austria (3), The Netherlands (3), Russia (1), Bulgaria (1), and Rumania (1). All metabolic and endocrinologic pediatric centers for $\mathrm{CHI}$ participated in this study. Thus, the obtained data are representative for Germany. Whenever possible the data were collected, by one of the authors, based on the medical records and were updated in co-operation with the patients' parents or the local treating physician. All data were obtained as a cross-sectional profile during the last 4 years by a questionnaire including detailed information on clinical symptoms, laboratory results, diagnostic and therapeutic procedures as well as follow-up findings. Neurologic and mental outcome were assessed by the physicians in charge of each patient usually in co-operation with a pediatric neurologist and psychologist, and were subdivided into three grades: normal, mild or severely abnormal. Neurologic outcome expresses the presence or absence of neurologic abnormalities, such as abnormal reflexes and tone, and represents the degree of motor development. Severely abnormal development was defined as severe abnormality of tone and movement leading to functional impairment and/or a delay in motor development. A mildly abnormal neurologic outcome was defined as a moderate abnormality of tone and movement leading to only minor functional impairment or a minor developmental delay. The mental outcome reflects the intellectual development of the child, as measured by psychological testing and the degree of schooling.

We included patients born between 1975 and 2002 . The mean age at the time of analysis was 14 years with a median age of about 11 years. Patients with transient neonatal hyperinsulinism with a spontaneous resolution within the first 3 months of life were not included in this study.

\section{Statistical analysis}

The $\chi^{2}$ test and Fisher exact test were used to test for the association between categorical variables, and the unpaired $t$-test was used to assess differences between groups. The results of $t$-tests were confirmed using the Mann-Whitney test for data that were not normally distributed. Binary logistic regression was used to determine factors predicting neurological outcome. Analyses were performed using SigmaStat version 2.0 (SPSS Inc., Chicago, IL, USA).

\section{Results}

\section{Age at onset and presenting symptoms}

Patients were attributed to one of three categories related to their onset of clinical symptoms. Those patients with neonatal onset $(n=74)$ became symptomatic usually within the first $48 \mathrm{~h}$ after birth (Table 1). Main symptoms included seizures followed

Table 1 Onset of clinical symptoms: different age groups.

\begin{tabular}{|c|c|c|c|}
\hline & $\begin{array}{l}\text { Neonatal manifestation } \\
\qquad(n=74)\end{array}$ & $\begin{array}{l}\text { Infantile manifestation } \\
\qquad(n=32)\end{array}$ & $\begin{array}{l}\text { Childhood manifestation } \\
\qquad(n=8)\end{array}$ \\
\hline \multicolumn{4}{|l|}{ Age of first symptoms } \\
\hline Mean & 2nd day & 5 months & 8.3 years \\
\hline Median & 1st day & 5 months & 7 years \\
\hline Range & $1-21$ days & $2-10$ months & 13 months -17 years \\
\hline \multicolumn{4}{|l|}{ Clinical symptoms } \\
\hline Seizure & $35(47.3 \%)$ & $27(84 \%)$ & $6(75.0 \%)$ \\
\hline Apnea & $20(27.0 \%)$ & $1(3.1 \%)$ & - \\
\hline Hypotonia & $20(27.0 \%)$ & $8(25 \%)$ & - \\
\hline Tremors & $19(25.7 \%)$ & $9(28.1 \%)$ & $1(12.5 \%)$ \\
\hline Cyanosis & $13(17.6 \%)$ & $3(9.4 \%)$ & $1(12.5 \%)$ \\
\hline Irregular respiration & $12(16.2 \%)$ & - & - \\
\hline Lethargy/changes in level of consciousness & $11(14.9 \%)$ & $14(43.8 \%)$ & $4(50.0 \%)$ \\
\hline Sweating & $8(10.8 \%)$ & $6(18.8 \%)$ & - \\
\hline Poor sucking & $8(10.8 \%)$ & - & - \\
\hline Irritability & $4(5.4 \%)$ & $1(3.1 \%)$ & - \\
\hline Bradycardia & $1(1.4 \%)$ & - & - \\
\hline
\end{tabular}


by lethargy, hypotonia, apnea and tremor (Table 1). Other patients were diagnosed by routine glucose screening for macrosomia or because of prematurity. Patients with infancy onset $(1-12$ months, $n=32)$

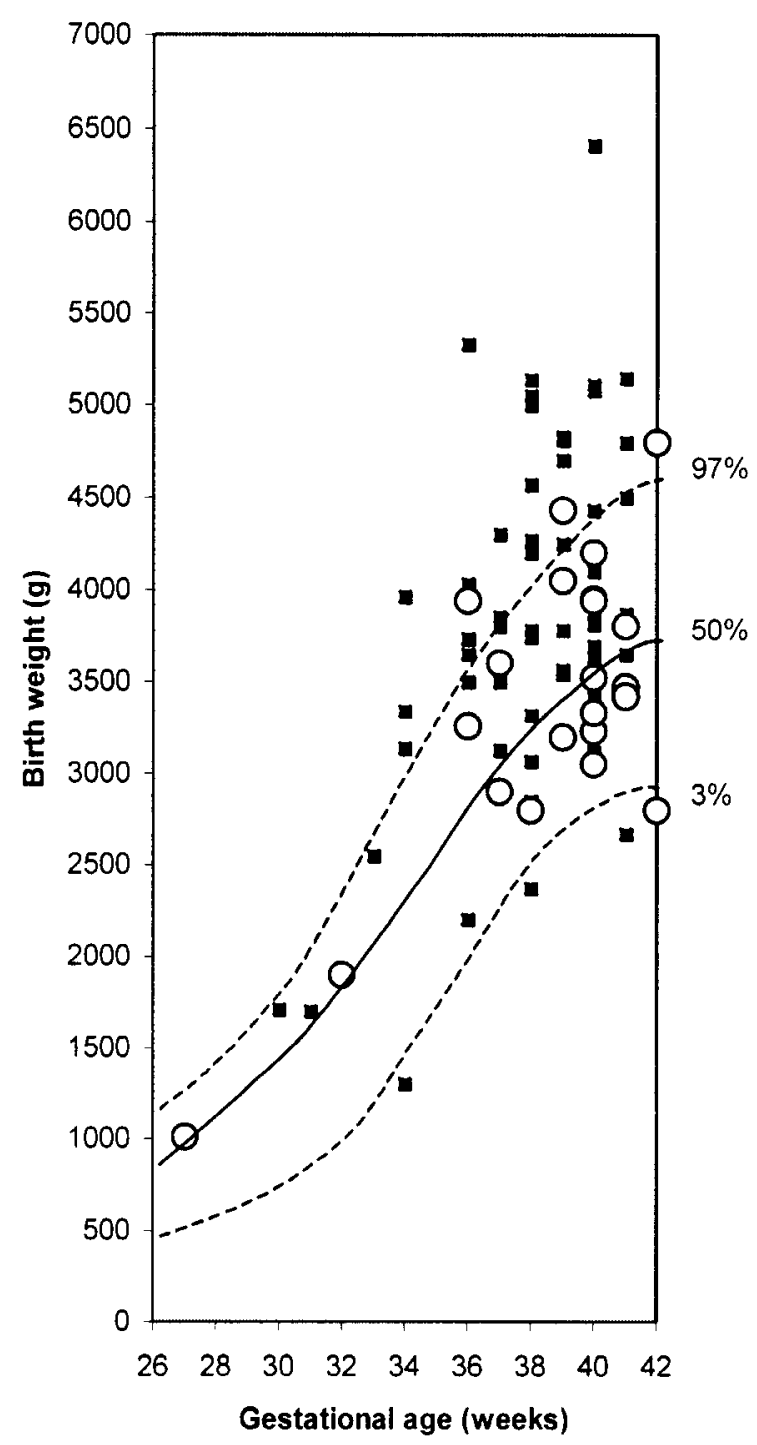

Figure 1 Birth weight for gestational age in patients with neonatal (squares) and infancy/childhood (circles) manifestation. and childhood-onset patients $(>12$ months, $n=8)$ usually became symptomatic with a hypoglycemic seizure.

\section{Parameters at birth}

Mean gestational age was 38 weeks (with a range of 27 to 42 weeks) and mean birth weight for this gestational age was $3670 \mathrm{~g}$ (Fig. 1). There was a bimodal pattern in distribution of birth weight with a subset (27\%) of patients with neonatal onset presenting with a birth weight $>2.0$ SDS (standard deviation scores) and a mean birth weight SDS of 3.2 (Table 2). The ratio for weight and length SDS was about 1.15 in patients with a birth weight $>2.0$ SDS. Whereas $85 \%$ of patients with high birth weight underwent surgery, the rate was $67 \%$ for the normal birth weight group (Table 2). However, we did not find significant differences with regard to treatment or neurological outcome between the groups of patients with normal birth weight and macrosomia (Table 2). In patients with neonatal onset the SDS of length and weight at birth were higher than for subjects with manifestation in infancy or childhood $(P=0.016, P=0.093$ respectively) (Fig. 2).

We did not find any differences with respect to the rate of psychomotor or mental retardation in later life, whether symptomatic hypoglycemia occurred on the first day of life or later during the first week. In addition, we observed a highly increased rate of premature births $\left(20 \% ; 99 \%\right.$ confidence interval $\left.\left(\mathrm{CI}_{99}\right)=10.5-29.5\right)$ which is significantly different from the normal population rate of about $5-7 \%$. Reasons for prematurity included a pathological cardiotocogram, preeclampsia, twin gestation or placenta praevia.

\section{Diagnosis}

For the neonatal-onset group diagnosis was usually based on carbohydrate requirement to prevent hypoglycemia $(17.6 \mathrm{mg} / \mathrm{kg} / \mathrm{min}$; range $12-28)$. Furthermore, a clearly measurable insulin $(>5 \mathrm{mU} / \mathrm{l})$ during hypoglycemia $(<2.6 \mathrm{mmol} / \mathrm{l})$ was found for all documented cases (Table 3). The lowest documented glucose concentration was significantly lower in

Table 2 Comparison of neonatal onset patients with very high birth weight ( $>2.0$ SDS) and the normal birth weight group.

\begin{tabular}{|c|c|c|c|c|c|c|c|c|c|c|}
\hline $\begin{array}{l}\text { Birth } \\
\text { weight }\end{array}$ & $n$ & $\begin{array}{l}\text { Mean birth } \\
\text { weight }\end{array}$ & $\begin{array}{c}\text { Mean } \\
\text { gestational } \\
\text { age }\end{array}$ & $\begin{array}{l}\text { Mean SDS } \\
\text { birth weight }\end{array}$ & $\begin{array}{l}\text { Response } \\
\text { to } \\
\text { diazoxide }\end{array}$ & $\begin{array}{l}\text { Operated } \\
\text { patients }\end{array}$ & $\begin{array}{c}\text { Re- } \\
\text { operation* }\end{array}$ & $\begin{array}{l}\text { Insulin- } \\
\text { dependent } \\
\text { diabetes } \\
\text { mellitis* }\end{array}$ & $\begin{array}{l}\text { Psychomotor } \\
\text { or mental } \\
\text { retardation }\end{array}$ & Epilepsy \\
\hline $\begin{array}{l}>2.0 \\
\text { SDS }\end{array}$ & 20 & 4676 & 38.0 & 3.15 & $15 \%$ & $85 \%$ & $38 \%$ & $43 \%$ & $35 \%$ & $20 \%$ \\
\hline $\begin{array}{c}\leq 2.0 \\
\text { SDS }\end{array}$ & 54 & 3385 & 38.2 & 0.25 & $31 \%$ & $67 \%$ & $30 \%$ & $27 \%$ & $33 \%$ & $22 \%$ \\
\hline
\end{tabular}

* The percentages for re-operation rate and insulin-dependent diabetes are based on the operated patients. 

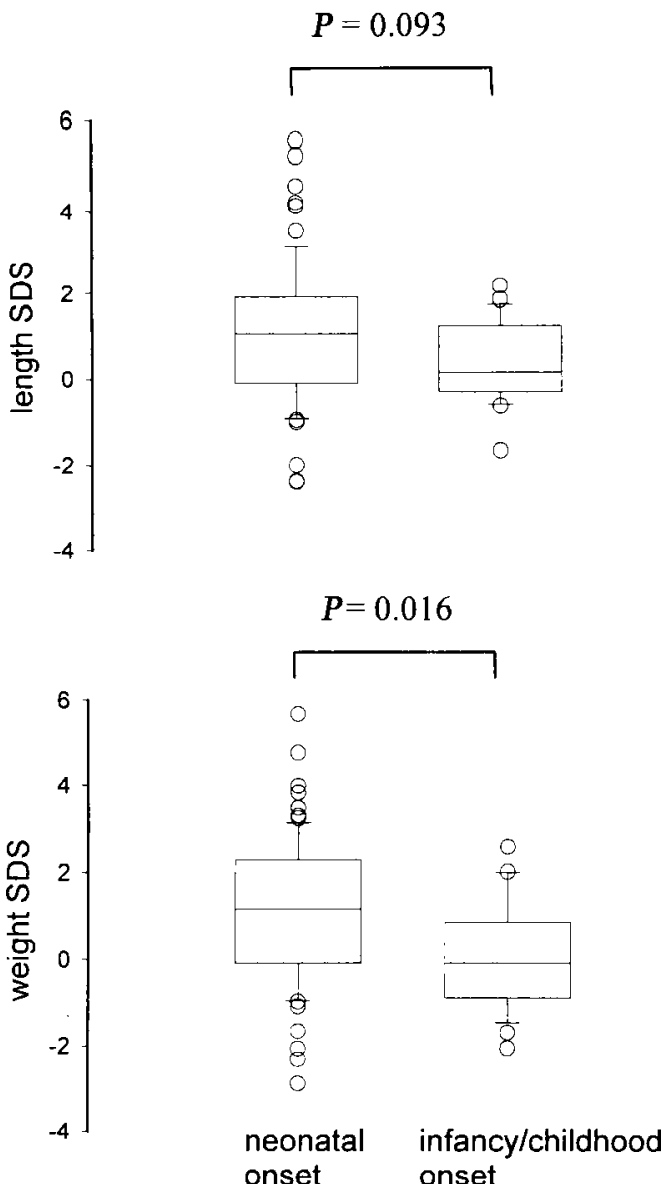

Figure 2 Comparison of neonatal and infancy/childhood onset for birth weight SDS (standard deviation score), and birth length SDS. The box plots represent medians and interquartile ranges, the error bars indicate 10th and 90th percentiles, and the circles represent individual values outside the 10th to 90th percentile range.

the neonatal-onset patients compared with infancy/ childhood-onset patients $(P<0.001)$.

\section{Treatment}

After diagnosis a therapeutic trial with diazoxide was usually introduced. A total number of 47 patients responded to diazoxide (up to $15 \mathrm{mg} / \mathrm{kg} /$ day) and were long-term treated with this drug. Severe side effects were not observed. In one patient, diazoxide was discontinued due to sinus tachycardia, in another two patients it was discontinued due to recurrent rush or severe anaphylactic reaction. Transient disturbances of serum electrolytes or edema were observed frequently. The patients who did not respond to diazoxide were usually operated patients. Only two patients were on a long-term treatment with octreotide. In the group of patients with neonatal onset and pancreatic surgery the time of surgery was highly variable: $40 \%$ (21) of the patients were operated on within the first 2 months of life but $25 \%$ (13) of the patients were operated on as late as after 6 months of age (Fig. 3). Furthermore, various amounts of pancreatic tissue were removed during initial surgery (Fig. 4): a small part of the organ confined to a focal adenomatous hyperplasia, $80-94 \%$ of the pancreas (subtotal resection), or $>95 \%$ of the pancreas (near total resection). Only $27 \%$ of all operated patients achieved stable long-term euglycemia after surgery without the need of further surgery or the development of hyperglycemia. In patients with subtotal pancreatectomy, the need for re-operation was similar as in patients who initially had a near-total pancreatectomy (Table 4 ).

\section{Outcome}

In general, a high frequency (44\%) of neurodevelopmental retardation was observed (Table 5). A broad differentiation into two groups revealed severe retardation in $18 \%$ and mild retardation in $26 \%$ of patients. Furthermore, $25 \%$ of all patients suffered from epilepsy. There was a higher incidence of mental retardation in the group of patients with infancy onset compared with the neonatal-onset group $\left(\chi^{2}=6.1\right.$, degrees of freedom $=1, P=0.01)$. For further analyses, patients were divided into a group with psychomotor or mental retardation and a group with normal development/normal intelligence (Table 6). Birth weight or lowest documented glucose concentration were not significantly different for both groups. Lack of euglycemia after pancreatic surgery was a risk

Table 3 Laboratory data for diagnosis of hyperinsulinism

\begin{tabular}{|c|c|c|c|}
\hline & $\begin{array}{l}\text { Neonatal onset } \\
(\text { mean (range)) }\end{array}$ & $\begin{array}{l}\text { Infantile onset } \\
\text { (mean (range)) }\end{array}$ & $\begin{array}{l}\text { Childhood onset } \\
\text { (mean (range)) }\end{array}$ \\
\hline $\begin{array}{l}\text { Glucose requirement to } \\
\text { maintain euglycemia ( } \mathrm{mg} / \mathrm{kg} / \mathrm{min})\end{array}$ & $17.6(12-28)$ & - & - \\
\hline $\begin{array}{l}\text { Number of patients with } \\
\text { documented increased insulin } \\
\text { (>5 mU/l) concentration during } \\
\text { hypoglycemia (glucose }<2.6 \mathrm{mmol} / \mathrm{l} \text { ) }\end{array}$ & $67 / 67$ & $24 / 24$ & $8 / 8$ \\
\hline $\begin{array}{l}\text { Lowest documented glucose } \\
\text { concentration }(\mathrm{mg} / \mathrm{dl})\end{array}$ & $1.33(0.50-2.22)$ & $1.78(1.28-2.33)$ & $1.72(1.39-2.22)$ \\
\hline
\end{tabular}




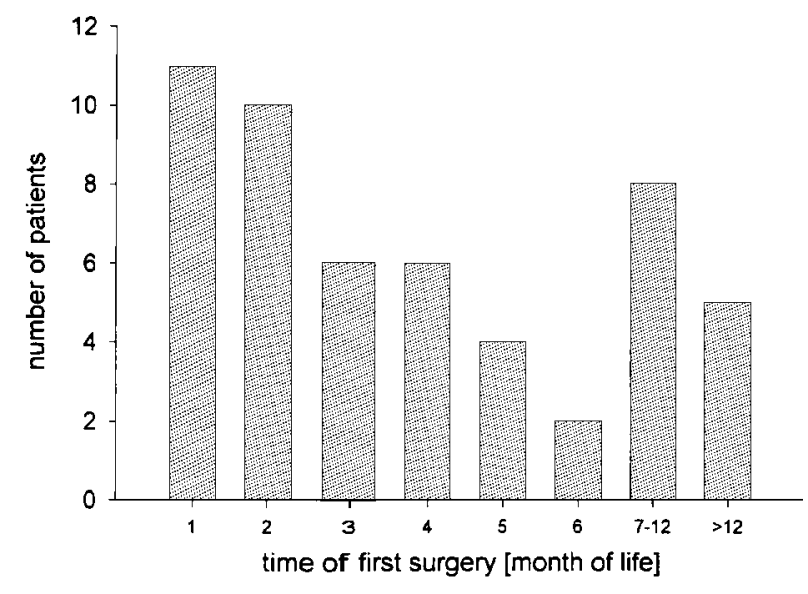

Figure 3 Time of first pancreatic resection in patients with neonatal onset hyperinsulinism.

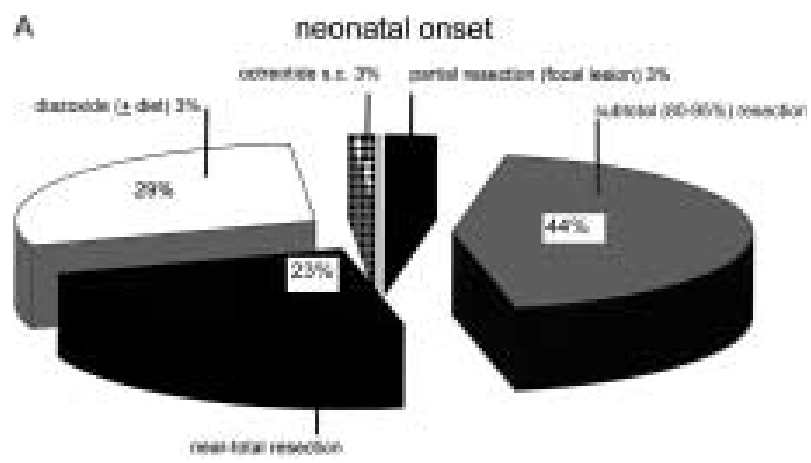

B

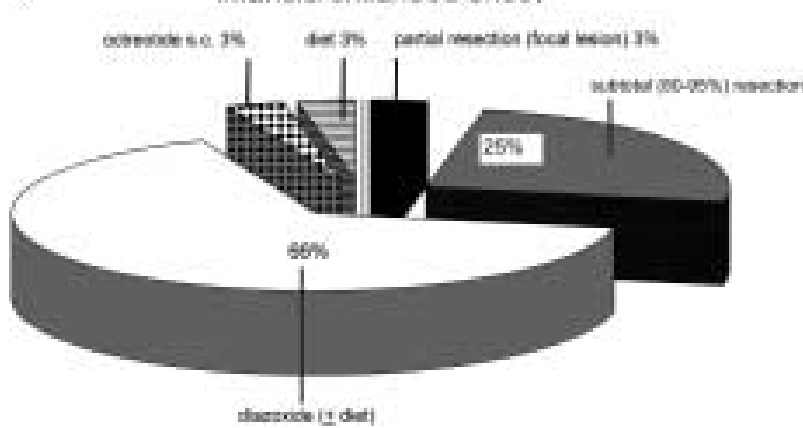

Figure 4 Long-term treatment in 114 patients with (A) neonatal onset or (B) infancy/childhood onset of congenital hyperinsulinism.

factor for mental retardation $\left(\mathrm{CI}_{90}=1.34-48.1\right.$; Fisher exact test: $P=0.04$ ).

All cases of insulin-dependent diabetes mellitus have occurred so far in the group of operated patients and in patients with neonatal onset of hyperinsulinism. The incidence of diabetes mellitus was particularly high after re-operation due to persistent hyperinsulinemic hypoglycemia (71\%). Insulin-dependent diabetes mellitus occurred most often either in the first year after pancreatectomy or between the age of 12 and
16 years. In seven patients diabetes mellitus was recognised before puberty and in 10 patients during puberty. In the group of operated patients without apparent diabetes mellitus the mean follow-up time was 6.6 years; one patient had finished puberty, two patients were at the end of puberty.

In general, in the course of treatment all patients showed a tendency to normalization of their body weight and length (Fig. 5). Apparently, neither longterm octreotide treatment $(n=2)$ nor a potential exocrine pancreatic insufficiency $(n=24$ precautionarily substituted with pancreatic enzymes) had a major influence on growth.

\section{Discussion}

In this study we performed a retrospective analysis of clinical and laboratory data and evaluated clinical presentation, diagnostic criteria, therapeutic approaches as well as outcome in 114 patients with CHI. Analysis focused on the characterization of the clinical phenotype of this heterogeneous disease and an evaluation of the factors predisposing for developmental delay. Patients may present during pregnancy with macrosomia and we found a significantly increased birth weight in the patients with neonatal onset of hyperinsulinism but not in patients with infancy or childhood onset. Insulin is known to promote anabolism in the fetus and an increased mean birth weight can be explained by prenatal hyperinsulinism and an unlimited fuel supply by the mother.

Of note, distribution of birth weight of the patients with neonatal onset was not only shifted to a higher mean birth weight, but a bimodal pattern of distribution was also evident with a second peak for patients presenting with a high birth weight $>2.0$ SDS and a mean SDS of 3.15. It seems likely that this increased birth weight in such affected patients reflects severe prenatal hyperinsulinism caused by $\mathrm{K}_{\mathrm{ATP}}$-channel defects. However, compared with the remaining neonatal patients no increased severity could be demonstrated with respect to clinical course or outcome. The marked differences in birth weights might be caused by different rates of glucose crossing the placenta by facilitated diffusion along a concentration gradient between maternal and fetal plasma. Macrosomia was only a finding during the neonatal period and the first months of life. After adequate treatment a general tendency to normalization of weight as well as length was observed. The mean data revealed a normal distribution in percentile ranges at the time of the last clinical visit.

Diagnosis in neonatal-onset patients is usually established by a high carbohydrate $(>15 \mathrm{mg} / \mathrm{kg} / \mathrm{min})$ intake to prevent hypoglycemia (5). In our group of patients glucose requirements ranged from 12 to $28 \mathrm{mg} / \mathrm{kg} / \mathrm{min}$ indicating that a level $>12 \mathrm{mg} / \mathrm{kg} / \mathrm{min}$ 
Table 4 Operative treatment in $\mathrm{CHI}$ patients.

\begin{tabular}{lccc}
\hline & Initial operation & Re-operation & Insulin-dependent diabetes mellitus \\
\hline Pancreatectomy & 3 & - & \\
Partial (focal lesion) & 43 & 12 & $12^{\star}$ \\
Subtotal $(80-94 \%)$ & 17 & 5 & 5 \\
Near-total $(\geq 95 \%)$ & & 5 & \\
\hline
\end{tabular}

* 10 of 12 after re-operation.

Table 5 Management and outcome in patients with respect to onset of symptoms.

\begin{tabular}{|c|c|c|c|c|}
\hline & Neonatal $(n=74)$ & Infantile $(n=32)$ & Childhood $(n=8)$ & Total $(n=114)$ \\
\hline Operative treatment & $70 \%$ & $25 \%$ & $38 \%$ & $55 \%$ \\
\hline Non-surgical treatment & $30 \%$ & $75 \%$ & $62 \%$ & $45 \%$ \\
\hline Neuro-developmental retardation & $34 \%$ & $63 \%$ & $50 \%$ & $44 \%$ \\
\hline Mild & $20 \%$ & $40 \%$ & $25 \%$ & $26 \%$ \\
\hline Severe & $14 \%$ & $23 \%$ & $25 \%$ & $18 \%$ \\
\hline Epilepsy & $22 \%$ & $27 \%$ & $50 \%$ & $25 \%$ \\
\hline
\end{tabular}

is already highly suspicious for hyperinsulinism. In addition, further blood tests were performed during hypoglycemia. It was further observed that in all tested individuals insulin was clearly measurable at the time of hypoglycemia. Once the diagnosis was confirmed, the first choice of treatment is diazoxide since this drug is orally administered and therefore suitable for long-term treatment. We found an adequate response to diazoxide and/or a carbohydrate-rich diet in $29 \%$ of the neonatal-onset group and in $69 \%$ of the patients with post-neonatal manifestation.
This rate is higher for the patients with neonatal onset compared with a French cohort of patients, where only $16 \%$ of neonates responded to diazoxide $(9,15,16)$. Nevertheless, even in diazoxide-responsive patients, further diagnostic procedures to identify a focal lesion have to be considered, since only enucleation of a focal lesion will really cure these patients (17). However, this recommendation does not include patients with moderate hyperammonemia who are highly suspicious for a hyperinsulinism/hyperammonemia syndrome (18) caused by germline mutations in

Table 6 Relationship of different clinical features, psychomotor retardation and normal psychomotor development.

\begin{tabular}{|c|c|c|c|c|}
\hline & $\begin{array}{l}\text { Psychomotor } \\
\text { or mental } \\
\text { retardation }\end{array}$ & $\begin{array}{c}\text { Normal } \\
\text { psychomotor } \\
\text { development }\end{array}$ & $\begin{array}{l}\text { Odds ratio and } \\
95 \% \text { confidence } \\
\text { interval }\end{array}$ & $\begin{array}{l}\text { Statistical significance }(P) \text { of } \\
\text { differences between psychomotor } \\
\text { retardation and normal developmen } \\
\text { group (by } t \text {-test/Mann-Whitney test) }\end{array}$ \\
\hline \multicolumn{5}{|l|}{ Neonatal onset } \\
\hline Yes (\%) & 36.7 & 66.1 & & \\
\hline No $(\%)$ & 63.3 & 33.9 & $3.38(1.37-8.34)$ & \\
\hline \multicolumn{5}{|l|}{ Response to diazoxide } \\
\hline Yes (\%) & 34.3 & 49.2 & & \\
\hline No $(\%)$ & 65.7 & 50.8 & $1.86(0.79-4.35)$ & \\
\hline \multicolumn{5}{|l|}{ Operative treatment } \\
\hline Yes (\%) & 51.2 & 54.9 & & \\
\hline No $(\%)$ & 48.8 & 45.1 & $1.16(0.54-2.51)$ & \\
\hline \multicolumn{5}{|l|}{ Extent of pancreatectomy } \\
\hline Subtotal (\%) & 88.2 & 67.6 & & \\
\hline Near total (\%) & 11.8 & 32.4 & $0.28(0.05-1.44)$ & \\
\hline \multicolumn{5}{|l|}{ Postoperative euglycemia } \\
\hline Yes $(\%)$ & 5.0 & 29.7 & & \\
\hline No $(\%)$ & 95.0 & 70.3 & $8.04(0.65-67.66)$ & \\
\hline \multicolumn{5}{|l|}{ Re-operation } \\
\hline Yes (\%) & 23.8 & 30.8 & & \\
\hline No $(\%)$ & 76.2 & 69.2 & $1.4(0.42-7.78)$ & \\
\hline Birth weight (SDS \pm S.E.M.) & $0.87 \pm 0.28$ & $0.83 \pm 0.22$ & & 0.91 \\
\hline $\begin{array}{l}\text { Lowest documented } \\
\text { glucose concentration } \\
\text { (mmol//; median) }\end{array}$ & 1.43 & 1.43 & & 0.27 \\
\hline $\begin{array}{l}\text { First operation (day of life; } \\
\text { mean } \pm \text { S.E.M.) }\end{array}$ & $360 \pm 98$ & $115 \pm 19$ & & 0.10 \\
\hline
\end{tabular}




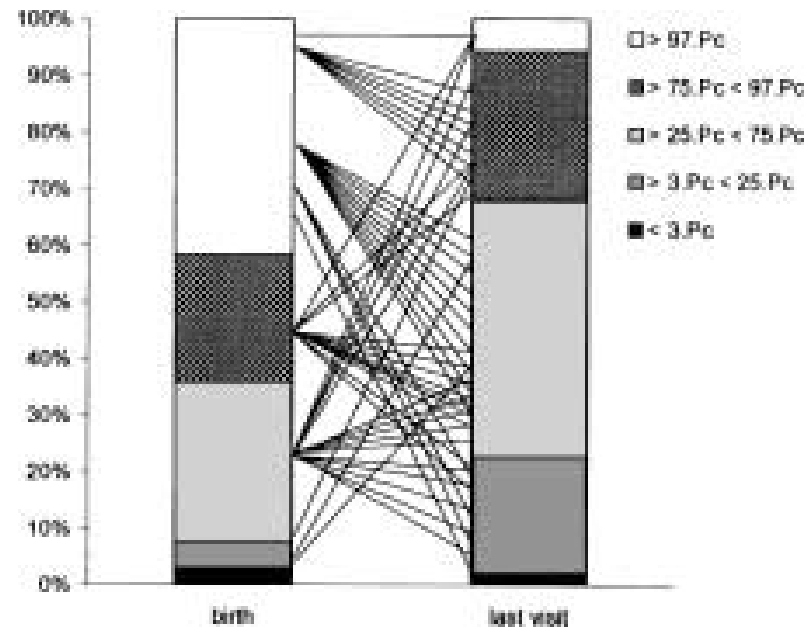

Figure 5 Weight development with weight percentiles at birth and at the last visit. Patients are divided into percentile (Pc) groups. Lines indicate the changes over time.

GLUD1. Blood ammonia concentrations were not systematically screened in our patients, but we recently reported mutational analysis data of 14 patients from seven families with hyperinsulinism/hyperammonemia syndrome (19). This condition seems not to be associated with focal pancreatic disease $(20,21)$.

In most patients non-responding to diazoxide, pancreatic surgery was performed. Only in two of them was an initial long-term treatment with the long-acting somatostatin analog, octreotide, initiated. Combination drug regimens were only used in single patients. In rare cases diazoxide, chlorothiazide, octreotide or nifedepin were used in combination. However, no representative data about the success of such combinations are available. Only two patients with a mild clinical form responded to nifedepin (22). Therefore, in more than half of all patients a pancreatic resection was performed. Since this follow-up study represents a time period over the last two decades surgery was usually performed without prior investigation localizing a focal lesion, e.g. by pancreatic venous sampling. Furthermore, we do not know the real incidence of focal lesions in our patient group since there was a lack of a clear histological differentiation between focal or diffuse forms in some cases. Probably the 'blind' pancreatic resections are one of the reasons why the overall success of pancreatic surgery was not satisfactory, yielding euglycemia in only $27 \%$ of patients after initial surgery. The consequence was a high rate of re-surgery, which also did not always result in eliminating hypoglycemia. The main reasons might include the fact that focal lesions in the head of the pancreas may be missed by blind pancreatic resections, and the general difficulty of achieving euglycemia by pancreatic surgery in patients with diffuse pancreatic disease. An improvement in adequate management will be achieved by the recently developed management recommendation by the ENRHI (European Network of Research in Hyperinsulinism) which proposes pancreatic venous sampling prior to surgery $(4,15,23,24)$. If no focal lesion is found during this procedure and a diffuse disease is likely, long-term octreotide treatment has to be considered, especially since after near total pancreatectomy or recurrent operations the risk of developing insulindependent diabetes mellitus is known to be greatly increased, especially after puberty $(11,12)$. At present, the overall incidence of insulin-dependent diabetes is about $27 \%$ for all operated patients after a mean follow-up period of 11 years. This rate is expected to increase noticeably with time, since most of the nondiabetic patients have not completed puberty. Diabetes mellitus was particularly high after re-operation $(71 \%)$. Of note, diabetes has so far occurred only in the group of neonatal-onset patients. This might be due to several factors: many fewer patients with post-neonatal onset were operated on; the extent of pancreatectomy was smaller; and the severity of hyperinsulinism may influence the rate of apoptosis of pancreatic $\beta$-cells. At the time of analysis only one of the patients with post-neonatal onset had completed puberty. The rate of diabetes might be reduced in future by improved acceptance and success of alternative octreotide treatment. This might be facilitated by the use of s.c. pumping systems with continuous application of the drug and lack of recurrent s.c. injections.

Finally, but most important the mental outcome in our patients showed a high degree of psychomotor or mental retardation. This rate was particularly increased in patients with infancy onset which is different from the patients reported by the French group where mental retardation occurred especially after neonatal onset of hyperinsulinism (25). Differences in the groups of patients in both studies may have contributed to these results. Patients presented here are from all kinds of different hospitals all over Germany, whereas in the French study patients are from one single center in Paris with a great reputation for the treatment of hyperinsulinism. Therefore, in the French report more severe cases from the whole of France and even Europe might have been included. In addition, we found patients with a syndromal type of disease presenting during infancy, and one major symptom of these patients included severe mental retardation (26). These findings suggest that mental retardation might not always be primarily and exclusively caused by hyperinsulinism. Another study performed in Argentina reported neurological impairment in 10 of 26 children with CHI (27), whereas a study from Greece which followed up $13 \mathrm{CHI}$ patients reported a good neurological outcome without any psychomotor retardation (28). The latter patients were mostly treated with drugs and only in two of 15 patients was pancreatectomy performed. This patient group probably represents a milder clinical phenotype. 
It is well known already that transient neonatal hypoglycemia or rare episodes of hypoglycemia of other causes are associated with neurodevelopmental deficits $(29,30)$. However, it is still surprising that despite early treatment in specialized units some patients with $\mathrm{CHI}$ develop severe mental deficits (25). Next to the problems that still exist in completely preventing episodes of hypoglycemia, a general influence of the underlying defect on the central nervous system function cannot be completely excluded. Mutational analyses are not available for most of our patients, but at least one protein that has been shown to be involved in the etiology of hyperinsulinism, the sulfonylurea receptor, is also present in the brain and dysfunction might contribute to the clinical course, in particular with respect to seizure disorders $(31,32)$.

In conclusion, our data show neurodevelopmental deficits in $44 \%$ of the patients, lack of euglycemia after pancreatic surgery in $73 \%$ of operated patients and a diabetes rate of $27 \%$ which is expected to increase with time. However, the long-acting somatostatin analog, octreotide, was rarely used and also the preoperative localizing of focal pancreatic lesions was barely realized. Furthermore, in the acute episode after initial manifestation even in individuals suffering from severe hyperinsulinism, normal glucose concentration can be achieved today by continuous carbohydrate supply and the use of glucagon or somatostatin. Therefore, improvement in the outcome of CHI patients might be achieved in future by increasing the awareness of the disease to achieve an early diagnosis, followed by an adequate treatment with definition of the anatomical lesion (focal or diffuse) prior to surgery and restriction of pancreatectomy to the minimal region necessary in the case of a focal lesion. Further substantial medical progress in the understanding and management of this heterogeneous disease now requires long-term prospective multidisciplinary international trials.

\section{Acknowledgements}

We are indebted to Dr K Mohnike and Dr W Rabl and to the numerous physicians who referred their patients for this study. The authors are also grateful to Dr B Beinbrech for support with the database. This work was supported by grants from the Arbeitsgemeinschaft für Pädiatrische Stoffwechselstörungen (APS) and the European Union (EU) (grant: QL61-CT-2000-00513).

\section{References}

1 Aynsley-Green A, Polak JM, Bloom SR, Gough MH, Keeling J, Ashcroft SJ et al. Nesidioblastosis of the pancreas: definition of the syndrome and the management of the severe neonatal hyperinsulinaemic hypoglycaemia. Archives of Disease in Childhood 1981 56 496-508.
2 Glaser B, Thornton P, Otonkoski T \& Junien C. Genetics of neonatal hyperinsulinism. Archives of Disease in Childhood Fetal and Neonatal Edition 200082 F79-F86.

3 Meissner T, Beinbrech B \& Mayatepek E. Congenital hyperinsulinism: molecular basis of a heterogeneous disease. Human Mutation $199913351-361$.

4 Aynsley-Green A, Hussain K, Hall J, Saudubray JM, Nihoul-Fekete $\mathrm{C}$, de Lonlay-Debeney $\mathrm{P}$ et al. Practical management of hyperinsulinism in infancy. Archives of Disease in Childhood Fetal and Neonatal Edition 200082 F98-F107.

5 Meissner T \& Mayatepek E. Clinical and genetic heterogeneity in congenital hyperinsulinism. European Journal of Pediatrics 2002 $1616-20$.

6 Kramer JL, Bell MJ, DeSchryver K, Bower RJ, Ternberg JL \& White NH. Clinical and histologic indications for extensive pancreatic resection in nesidioblastosis. American Journal of Surgery 1982 $143116-119$.

7 Spitz L, Bhargava RK, Grant DB \& Leonard JV. Surgical treatment of hyperinsulinaemic hypoglycaemia in infancy and childhood. Archives of Disease in Childhood 199267 201-205.

8 Thomas CGJ, Cuenca RE, Azizkhan RG, Underwood LE \& Carney $\mathrm{CN}$. Changing concepts of islet cell dysplasia in neonatal and infantile hyperinsulinism. World Journal of Surgery 198812 598-609.

9 de Lonlay-Debeney P, Poggi-Travert F, Fournet JC, Sempoux C, Vici CD, Brunelle F et al. Clinical features of 52 neonates with hyperinsulinism. New England Journal of Medicine 1999340 1169-1175.

10 Rahier J, Sempoux C, Fournet JC, Poggi F, Brunelle F, Nihoul-Fekete C et al. Partial or near-total pancreatectomy for persistent neonatal hyperinsulinaemic hypoglycaemia: the pathologist's role. Histopathology 199832 15-19.

11 Leibowitz G, Glaser B, Higazi AA, Salameh M, Cerasi E \& Landau H. Hyperinsulinemic hypoglycemia of infancy (nesidioblastosis) in clinical remission: high incidence of diabetes mellitus and persistent beta-cell dysfunction at long-term follow-up. Journal of Clinical Endocrinology and Metabolism 199580 386-392.

12 Cade A, Walters M, Puntis JW, Arthur RJ \& Stringer MD. Pancreatic exocrine and endocrine function after pancreatectomy for persistent hyperinsulinaemic hypoglycaemia of infancy. Archives of Disease in Childhood $1998 \mathbf{7 9} 435-439$.

13 Glaser B, Hirsch HJ \& Landau H. Persistent hyperinsulinemic hypoglycemia of infancy: long-term octreotide treatment without pancreatectomy. Journal of Pediatrics 1993123 644-650.

14 Rahier J, Sempoux C, Fournet JC, Poggi F, Brunelle F, Nihoul-Fekete $\mathrm{C}$ et al. Partial or near-total pancreatectomy for persistent neonatal hyperinsulinaemic hypoglycaemia: the pathologist's role. Histopathology 199832 15-19.

15 De Lonlay P, Fournet JC, Touati G, Groos MS, Martin D, Sevin C et al. Heterogeneity of persistent hyperinsulinaemic hypoglycaemia. A series of 175 cases. European Journal of Pediatrics 2002 $16137-48$.

16 Touati G, Poggi-Travert F, Ogier DB, Rahier J, Brunelle F, NihoulFekete $\mathrm{C}$ et al. Long-term treatment of persistent hyperinsulinaemic hypoglycaemia of infancy with diazoxide: a retrospective review of 77 cases and analysis of efficacy-predicting criteria. European Journal of Pediatrics 1998157 628-633.

17 Rahier J, Guiot Y \& Sempoux C. Persistent hyperinsulinaemic hypoglycaemia of infancy: a heterogeneous syndrome unrelated to nesidioblastosis. Archives of Disease in Childhood Fetal and Neonatal Edition $2000 \mathbf{8 2}$ F108-F112.

18 Stanley CA, Lieu YK, Hsu BY, Burlina AB, Greenberg CR, Hopwood NJ et al. Hyperinsulinism and hyperammonemia in infants with regulatory mutations of the glutamate dehydrogenase gene. New England Journal of Medicine $1998 \mathbf{3 3 8}$ $1352-1357$.

19 Santer R, Kinner M, Passarge M, Superti-Furga A, Mayatepek E, Meissner T et al. Novel missense mutations outside the allosteric domain of glutamatedehydrogenase are prevalent in European 
patients with the congenital hyperinsulinism-hyperammonemia syndrome. Human Genetics 2001108 66-71.

20 MacMullen C, Fang J, Hsu BY, Kelly A, de Lonlay-Debeney P, Saudubray JM et al. Hyperinsulinism/hyperammonemia syndrome in children with regulatory mutations in the inhibitory guanosine triphosphate-binding domain of glutamate dehydrogenase. Journal of Clinical Endocrinology and Metabolism $2001 \mathbf{8 6}$ $1782-1787$.

21 Stanley CA, Fang J, Kutyna K, Hsu BY, Ming JE, Glaser B et al. Molecular basis and characterization of the hyperinsulinism/ hyperammonemia syndrome: predominance of mutations in exons 11 and 12 of the glutamate dehydrogenase gene. HI/HA Contributing Investigators. Diabetes $200049667-673$.

22 Eichmann D, Hufnagel M, Quick P \& Santer R. Treatment of hyperinsulinaemic hypoglycaemia with nifedipine. European Journal of Pediatrics 1999158 204-206.

23 Dubois J, Brunelle F, Touati G, Sebag G, Nuttin C, Thach T et al. Hyperinsulinism in children: diagnostic value of pancreatic venous sampling correlated with clinical, pathological and surgical outcome in 25 cases. Pediatric Radiology 199525 512-516.

24 Ferry RJJ, Kelly A, Grimberg A, Koo-McCoy S, Shapiro MJ, Fellows KE et al. Calcium-stimulated insulin secretion in diffuse and focal forms of congenital hyperinsulinism. Journal of Pediatrics 2000 $137239-246$.

25 Menni F, de Lonlay P, Sevin C, Touati G, Peigne C, Barbier V et al. Neurologic outcomes of 90 neonates and infants with persistent hyperinsulinemic hypoglycemia. Pediatrics 2001107 476-479.
26 Meissner T, Rabl W, Mohnike K, Scholl S, Santer R \& Mayatepek E. Hyperinsulinism in syndromal disorders. Acta Paediatrica $200190856-859$.

27 Cresto JC, Abdenur JP, Bergada I \& Martino R. Long-term follow up of persistent hyperinsulinaemic hypoglycaemia of infancy. Archives of Disease in Childhood 1998 79 440-444.

28 Dacou-Voutetakis C, Psychou F \& Maniati-Christidis M. Persistent hyperinsulinemic hypoglycemia of infancy: long-term results. Journal of Pediatric Endocrinology and Metabolism $1998 \quad 11$ $131-141$.

29 Duvanel CB, Fawer CL, Cotting J, Hohlfeld P \& Matthieu JM. Longterm effects of neonatal hypoglycemia on brain growth and psychomotor development in small-for-gestational-age preterm infants. Journal of Pediatrics 1999134 492-498.

30 Rovet JF \& Ehrlich RM. The effect of hypoglycemic seizures on cognitive function in children with diabetes: a 7-year prospective study. Journal of Pediatrics 1999134 503-506.

31 Ashcroft FM, Ashcroft SJ \& Harrison DE. Properties of single potassium channels modulated by glucose in rat pancreatic betacells. Journal of Physiology $1988 \mathbf{4 0 0} 501-527$.

32 Hernandez-Sanchez C, Basile AS, Fedorova I, Arima H, Stannard B, Fernandez AM et al. Mice transgenically overexpressing sulfonylurea receptor 1 in forebrain resist seizure induction and excitotoxic neuron death. PNAS 200198 3549-3555.

Received 12 November 2002

Accepted 1 April 2003 